\title{
Spatial genetic structure in the Laperrine's olive (Olea europaea subsp. laperrinel), a long-living tree from the central Saharan mountains
}

\author{
G Besnard ${ }^{1}$, PA Christin ${ }^{1}$, D Baali-Cherif ${ }^{2}, \mathrm{~N}_{\text {Bouguedoura }}{ }^{2}$ and F Anthelme ${ }^{3}$ \\ ${ }^{1}$ Department of Ecology and Evolution, Biophore, University of Lausanne, Lausanne, Switzerland; ${ }^{2}$ BP44, Laboratoire de Recherche sur \\ les Zones Arides, USTHB/INA, Alger, Algeria and ${ }^{3}$ UMR Diversité et Adaptation chez les Plantes Cultivées, IRD, Montpellier, France
}

\begin{abstract}
The Laperrine's olive (Olea europaea subsp. laperrinei) is an emblematic species of the Sahelo-Saharan Mountains. Populations of this tree are locally threatened by extinction due to climatic vicissitudes and human activities, particularly in Niger and Algeria. In order to study the spatial genetic structure and the dynamics of $O$. e. laperrinei populations, we sampled trees in four isolated mountain ranges (Tassili n'Ajjer and Hoggar (Algeria), Tamgak and Bagzane (Niger)). A total of 237 genets were identified using nuclear microsatellites. Phylogenetic reconstruction based on plastid DNA data supported a maternal origin of $O$. e. laperrinei populations in South Algeria, where a higher allelic richness was observed. Based on nuclear microsatellite data, two levels of structure were revealed: first, individuals from Niger and Algeria were separated in two distinct groups; second,
\end{abstract}

four less differentiated clusters corresponded to the four studied mountain ranges. These results give support to the fact that desert barriers have greatly limited long distance gene flow. Within populations, pairwise kinship coefficients were significantly correlated to geographical distance for Niger populations but not for Algerian mountains. Historical factors and habitat heterogeneity may explain the differences observed. We conclude that the Hoggar acts as an important genetic reservoir that has to be taken into account in future conservation programmes. Moreover, very isolated endangered populations (for example, Bagzane) displaying evident genetic particularities have to be urgently considered for their endemism.

Heredity (2007) 99, 649-657; doi:10.1038/sj.hdy.6801051; published online 12 September 2007

Keywords: conservation genetics; microsatellites; olive tree; plastid DNA; spatial autocorrelation; threatened species

\section{Introduction}

The Saharan desert covers a large part of central Africa. Since the upper Miocene, it represents a natural barrier between Mediterranean and Tropical Africa which is difficult to cross for living organisms (Douady et al., 2003). The number of species present in this area is particularly limited (Quézel, 1965), but the ratio of endemic species is relatively high in mountains that act as refugia for plants and animals due to higher rainfall in altitude. The Saharan flora has affinities with those from adjacent regions, mainly with the Mediterranean Basin, Arabia, Sahelian and Tropical Africa (Quézel, 1978, 1997). Genetic studies have confirmed that some Saharan species are closely related to Mediterranean taxa (for example, Senecio, Coleman et al., 2003; Atriplex, OrtízDorba et al., 2005; Erica, McGuire and Kron, 2005). But they have also revealed complex biogeograhic history for the Laperrine's olive populations (Olea europaea L. subsp. laperrinei (Cif.) Batt. and Trab.), which may be due to recurrent migration events from both Mediterranean and Tropical Africa (Besnard et al., 2007). In the Saharan

Correspondence: Dr G Besnard, Department of Ecology and Evolution, Biophore, University of Lausanne, Biophore, Lausanne 1015, Switzerland. E-mail: gbesnard@unil.ch

Received 17 November 2006; revised 26 July 2007; accepted 6 August 2007; published online 12 September 2007 mountains, long-term persistence of some species, particularly long-living trees, is uncertain, mostly due to their geographic isolation, their low regeneration associated with the impact of human activities and climatic vicissitudes. For instance, Cupressus dupreziana A. Camus (from the Tassili $\mathrm{n}^{\prime}$ Ajjer) is classified as endangered taxon in the IUCN Red list (Abdoun and Beddiaf, 2002), while some others, such as the Laperrine's olive, are currently distributed in a highly fragmented habitat and locally threatened by extinction (Quézel, 1997). Moreover, an expected increase of local human activities (Anthelme et al., 2006) as well as future global changes (Williams et al., 2007) may add to the high isolation of the Saharan flora. It could then become even more vulnerable to a reduction of the favourable areas, particularly in the Niger mountains where the altitudinal range is smaller than in South Algeria.

The populations of O. e. laperrinei have regressed with the desert expansion during the Pleistocene (Wickens, 1976; Quézel, 1978; Maley, 1980). Small populations are present in mountains from central Sahara (Algeria: Hoggar, Tassili n'Ajjer, Mouydir; and Niger: Greboun, Tamgak, Bagzane) to northeast Sudan (Jebel Marra, Gourgueil). This tree grows at relatively high altitudes (generally from 1400 to $2700 \mathrm{~m}$ ) on volcanic or eruptive rocks and its populations are often difficult to reach. It persists in very dry areas particularly in southern Algeria where mean rainfall can be less than $50 \mathrm{~mm}$ per year 
(Quézel, 1965; Médail et al., 2001). The persistence of this taxon could then be seriously affected by future environmental changes (Baali-Cherif and Besnard, 2005). Today, the wood of this tree is rarely exploited by humans but camels and goats intensively browse young shoots. This limits the possibility of regeneration of the O. e. laperrinei populations, which is considered as null by several authors (Maire, 1933; Quézel, 1978). However, even if survival of young trees has never been observed, a slow regeneration of populations cannot be excluded as reported for $C$. dupreziana in the Tassili n'Ajjer (Abdoun and Beddiaf, 2002; Abdoun et al., 2005). The species is also considered as an emblematic tree for its very long persistence and rarity (Wickens, 1976). As a consequence, the preservation of $O$. e. laperrinei populations may have an increasing importance with the development of the eco-tourism in northern Niger and southern Algeria, but to date, the means given for their protection are still very limited.

For conservation purposes, the inventory of genetic resources of this Saharan relict tree is needed to understand the past and future evolution of its populations. Studying partition of the genetic diversity between and within populations can help unravel the dynamic of gene flow (for example, Baldoni et al., 2006; Rubio de Casas et al., 2006; Belaj et al., 2007) and assess the importance of some geographic and biological features, such as habitat fragmentation, altitudinal distribution, clonal growth and lifespan of individuals. For instance, one can expect that desert barriers may have greatly limited gene flows between distant mountains and that small populations are more affected by stochastic effects (for example, genetic drift). Knowledge of population genetics may then provide baseline information for optimized management strategies (Escudero et al., 2003) through the identification of areas that should preferentially beneficiate of a conservation programme, for example, because of a high genetic diversity or endemism.

In this context, a study on the genetic diversity of O. e. laperrinei populations from South Algeria and Niger is conducted with two main objectives: (1) to analyse the genetic structure of populations distributed in four isolated mountain ranges from Algeria and Niger using ptDNA and nuclear microsatellites. In particular, the allelic richness and the genetic differentiation between populations are assessed; and (2) to assess the importance of gene flow within each mountain range. A spatial autocorrelation analysis is performed to measure the degree of spatial genetic structure (SGS) at the population scale. Based on our observations, we discuss the dynamic of $O$. e. laperrinei populations in the central Saharan mountains and propose some possible conservation strategies.

\section{Materials and methods}

\section{Plant material}

To complete the data sample of subsp. laperrinei from South Algeria and North Niger previously analysed by Baali-Cherif and Besnard (2005) and Anthelme et al. (accepted), we prospected 64 additional tree samples in the Tassili n'Ajjer (southeast Algeria; Table 1). Clonal growth was previously shown (Baali-Cherif and Besnard, 2005; Anthelme et al., accepted) and only appar- ently unconnected ramets (individualized trunks) were sampled as already reported. Geographical coordinates of all trees were reported in each of the four mountain ranges sampled. Additionally, for four other localities (Assekrem, Jabbârene, In Acoulmou and Jebel Marra' crater), one to three ramets were also characterized (Table 1). A total of 311 ramets (including four herbarium samples from the Jebel Marra and the Tefedest) were analysed.

\section{Genetic markers}

To investigate the phylogenetic relationships between populations from Niger, Sudan and Algeria, polymorphism at 20 sites (10 microsatellite or indel loci and 10 PCRRFLPs) of the plastid DNA (ptDNA) was investigated: ccmp5 and ccmp7 from Weising and Gardner (1999), 14 loci from Besnard et al. (2003) and four loci from BaaliCherif and Besnard (2005). A total of 50 individuals (sampled in each mountain range) were characterized for each locus. The polymorphic loci were then used to characterize the whole sample. These ptDNA data allowed the investigation of (i) the phylogenetic relationships between populations and (ii) the genetic differentiation between populations based on a maternal marker.

Lastly, the SGS was investigated with nuclear microsatellite (simple sequence repeat (SSR)) markers. To characterize all sampled ramets from the Tassili n'Ajjer and the Assekrem, nine SSR loci were used as reported in Baali-Cherif and Besnard (2005) and Anthelme et al. (accepted): ssrOeUA-DCA1, ssrOeUA-DCA3, ssrOeUADCA8, ssrOeUA-DCA9, ssrOeUA-DCA14, ssrOeUADCA15 (Sefc et al., 2000), GAPU45 (Carriero et al., 2002), PA(ATT)2 (Saumitou-Laprade et al., 2000) and EMO03 (de la Rosa et al., 2002). For these nine loci, an absence or a very low frequency of null alleles was reported in subsp. laperrinei by Baali-Cherif and Besnard (2005). A total of 307 ramets (Table 1) were characterized with the nine SSR loci in the present work and in previous studies (Baali-Cherif and Besnard, 2005; Anthelme et al., accepted).

\section{Data analyses}

The phylogenetic relationships between ptDNA haplotypes detected in subsp. laperrinei were analysed using a reduced Median network reconstructed with the NETWORK software (http://www.fluxus-engineering.com/ sharenet.htm; Bandelt et al., 1999). All haplotypes belonging to sub-lineage E1 not detected in subsp. laperrinei (haplotypes 1, 2 (subsp. europaea) and 8 (subsp. cuspidata); Besnard et al., 2007) were also included in this analysis. In addition, haplotype no. 10 (sub-lineage E3 (subsp. europaea); Besnard et al., 2007) was considered as out-group. This haplotype was closely related to sublineage E1 (Besnard et al., 2007).

Based on nuclear SSR data, identical genotypes were identified on several independent ramets and we had to evaluate whether they represented the same individual (or genet). The probability that a zygote acquires a given diploid genotype, $P_{\text {gen }}$ was calculated, following Parks and Werth (1993). Population genetic analyses were then performed based on all distinct individuals. In order to account for different sample sizes of populations, allelic richness $\left(R_{S}\right)$ was estimated for all SSR and ptDNA loci in each mountain range using the FSTAT software 
Table 1 Geographic origin of the O. e. laperrinei populations and number of genets characterized for ptDNA and SSR genotyping

\begin{tabular}{|c|c|c|c|c|c|c|}
\hline Mountain range, country & Locality & Altitude $(m)$ & Latitude & Longitude & $P t D N A^{\mathrm{a}}$ & $S S R^{\mathrm{a}}$ \\
\hline Hoggar, Algeria & $\begin{array}{l}\text { Adjelella } \\
\text { Adrar Heggueghene } \\
\text { Issekrâm } \\
\text { Tanarouatine } \\
\text { Assekrem, Atakor } \\
\text { In Acoulmou, Tefedest }^{c}\end{array}$ & $\begin{array}{l}1530 \\
1390-1600 \\
1525-1605 \\
1580-1600 \\
\sim 2500 \\
\sim 2200\end{array}$ & $\begin{array}{l}22^{\circ} 38^{\prime} \mathrm{N} \\
22^{\circ} 47^{\prime} \mathrm{N} \\
22^{\circ} 50^{\prime} \mathrm{N} \\
23^{\circ} 06^{\prime} \mathrm{N} \\
23^{\circ} 15^{\prime} \mathrm{N} \\
24^{\circ} 22^{\prime} \mathrm{N}\end{array}$ & $\begin{array}{l}5^{\circ} 30^{\prime} \mathrm{E} \\
5^{\circ} 37^{\prime} \mathrm{E} \\
5^{\circ} 33^{\prime} \mathrm{E} \\
6^{\circ} 03^{\prime} \mathrm{E} \\
5^{\circ} 35^{\prime} \mathrm{E} \\
5^{\circ} 36^{\prime} \mathrm{E}\end{array}$ & $\begin{array}{r}9 \\
57 \\
16 \\
8 \\
3 \\
2\end{array}$ & $\begin{aligned} & 9(10)^{\mathrm{b}} \\
& 57(65) \\
& 16(17) \\
& 8(13) \\
& 3(3) \\
&-\end{aligned}$ \\
\hline Tassili n'Ajjer, Algeria & $\begin{array}{l}\text { Tamrit } \\
\text { Jabbârene, Akba-Aroûm }\end{array}$ & $\begin{array}{l}1600-1710 \\
\sim 1750\end{array}$ & $\begin{array}{l}24^{\circ} 37^{\prime} \mathrm{N} \\
24^{\circ} 28^{\prime} \mathrm{N}\end{array}$ & $\begin{array}{l}9^{\circ} 35^{\prime} \mathrm{E} \\
9^{\circ} 43^{\prime} \mathrm{E}\end{array}$ & $\begin{array}{r}45 \\
1\end{array}$ & $\begin{array}{l}45(63) \\
1(1)\end{array}$ \\
\hline Tamgak, Niger & Faille du Tamgak & $1635-1810$ & $19^{\circ} 03^{\prime} \mathrm{N}$ & $8^{\circ} 39^{\prime} \mathrm{E}$ & 45 & $45(55)$ \\
\hline Bagzane, Niger & Gomous-Bagzan'n'amas & $1550-1850$ & $17^{\circ} 49^{\prime} \mathrm{N}$ & $8^{\circ} 46^{\prime} \mathrm{E}$ & 52 & $52(78)$ \\
\hline Egalah, Niger & Egalah & $\sim 1650$ & $18^{\circ} 10^{\prime} \mathrm{N}$ & $8^{\circ} 41^{\prime} \mathrm{E}$ & 1 & $1(2)$ \\
\hline Jebel Marra, Sudan & Jebel Marra' crater & $\sim 2500$ & $13^{\circ} 10^{\prime} \mathrm{N}$ & $24^{\circ} 22^{\prime} \mathrm{E}$ & 2 & - \\
\hline
\end{tabular}

Abbreviation: SSR, simple sequence repeat.

${ }^{\mathrm{a}}$ The number of genets per population characterized is given for each marker type.

${ }^{b}$ The number of ramets analysed using SSR data is given within parentheses.

${ }^{\mathrm{c}}$ From herbarium samples see Besnard et al. (2007).

(Goudet, 1995). The total genetic diversity $\left(H_{\mathrm{T}} ; \mathrm{Nei}, 1987\right)$ was also estimated for each locus and each population. In order to get samples of comparable sizes and densities, individuals or patches distant from the core population of each mountain range were not considered. Thus, concerning the Hoggar, only the 57 individuals from the Adrar Heggueghene were used. A paired $t$-test (one-sided) was used to evaluate the significance of the differences of allelic richness (at nuclear loci) between each pair of populations. Similarly, a Wilcoxon test (nonparametric test) was used to evaluate the significance of the difference of gene diversity at nuclear SSR loci. Furthermore, the number of genetically homogeneous clusters $(K)$ in the dataset was determined using a modelbased clustering method implemented in the STRUCTURE software (Pritchard et al., 2000). Bayesian analysis was run under the admixture model for 1000000 generations after a burn-in period of 100000 . Analyses were run for $K$ between 1 and 10 with 10 iterations for each $K$-value. The most likely number of clusters was determined using the log probability of data as well as the absolute values of the second order rate of change of the likelihood distribution divided by the s.d. of the likelihoods $(\Delta K)$ following the recommendations given by Evanno et al. (2005). We also computed $F_{\mathrm{ST}}$ based on nuclear SSR data for each pair of populations according to Weir and Cockerham (1984) using FsTAT (Goudet, 1995). Given the lack of ptDNA polymorphism, we did not compute $F_{\mathrm{ST}}$ based on plastid markers. Significance of $F_{\mathrm{ST}}$ was tested using a permutation test. $F_{\text {IS }}$ (fixation index) was also computed for each population using FSTAT. $F_{\text {IS }}$ were tested for deviation from Hardy-Weinberg equilibrium by comparing the $F_{\mathrm{IS}}$ values computed from the observed data with values derived by randomly permuting (5000 times) the alleles among individuals.

The software BOTTLENECK version 1.2.02 (Piry et al., 1999) was used to evaluate recent effective population size reductions in each mountain range. The two-phased model of mutation was applied with 5\% of multi-step changes as recommended by Luikart and Cornuet (1998) for microsatellite markers. The same model with $30 \%$ of multi-step changes and the stepwise mutation model were also tested.

To assess isolation by distance, the fine-scale SGS was investigated using a spatial autocorrelation method for each mountain range separately. In order to get samples of comparable sizes and densities, individuals or patches distant from the core population of each mountain range were not used for analyses. Thus, the individual from Jabbârene (Tassili n'Ajjer) was removed, and only the 57 individuals from the Adrar Heggueghene were considered in the Hoggar. Genetic relationships between all pairs of individuals within the same mountain range were regressed on the logarithmic geographical distance separating them by using SPAGEDi (Hardy and Vekemans, 2002). The kinship coefficient from Loiselle et al. (1995), robust against the presence of low frequency alleles, was used. Reference allele frequencies used to compute pairwise kinships were those of the whole sample. Significance of the regression coefficients was assessed through 10000 permutations. In order to illustrate the trend of the relation between genetic and geographic distances, mean kinship coefficients were calculated for up to 10 distance intervals within each mountain range.

\section{Results}

\section{Plastid DNA polymorphism and phylogenetic} relationships between $O$. e. laperrinei populations Six ptDNA haplotypes have been found in the O. e. laperrinei populations based on polymorphism of three ptDNA microsatellite loci (ccmp5, trnT-L-polyT and psbK-trnS-polyT/A; see Supplementary Material). One haplotype (no. 41) was observed for the first time in the present study. Five haplotypes were restricted to a specific mountain range: haplotype no. 7 to the Jebel Marra, haplotype no. 41 to the Bagzane and the Egalah, and haplotypes nos. 4, 5 and 6 to the Hoggar (Figure 1a). 
Haplotype no. 3 was the most frequent one (73\%) and was distributed in three mountain ranges (Hoggar, Tassili n'Ajjer and Tamgak). Phylogenetic relationships between haplotypes were inferred by Parsimony analysis (Figure 1b). Mediterranean haplotype no. 10 (out-group) allowed a polarization of the network. Interestingly, haplotype no. 3 displayed a basal position in sub-lineage E1, suggesting that it displays an ancestral state for the three microsatellite polymorphic loci.

\section{Evidence of clonal growth in populations}

A total of 109 alleles were revealed with the 9 nuclear SSR loci (Table 2). Among the 307 ramets analysed using SSRs, we recognized 237 distinct genets. A total of 54 $(22.8 \%)$ genets were assigned to at least 2 ramets (13 $(14 \%)$ in the Hoggar, $12(26.1 \%)$ in the Tassili n'Ajjer, 21 $(40.4 \%)$ in the Bagzane, $1(100 \%)$ in the Egalah and 6 $(13.3 \%)$ in the Tamgak). For these genets, the probability of obtaining the same genetic profile $\left(P_{\text {gen }}\right)$ was extremely low, ranging from $7.2 \times 10^{-5}$ (Bagzane no. 15 and 16) to $3.1 \times 10^{-13}$ (Tamrit nos. 51 and 52). Moreover, in every case these ramets were sampled on the same site and at a relatively small distance (less than $50 \mathrm{~m}$ ). Consequently, we considered that two undistinguished ramets corresponded to different samples of the same plant and only one ramet per individual was considered for population genetic analyses.

\section{Population genetic analyses}

Gene diversity $\left(H_{\mathrm{T}}\right)$ and allelic richness $\left(R_{\mathrm{S}}\right)$ were compared between the four main mountain ranges investigated (Table 2). Similar gene diversity values (ranging from 0.60 to 0.65 ) were observed in each mountain range. In contrast, the Hoggar displayed the highest allelic richness for both nuclear DNA and ptDNA loci. Thus, for nuclear SSRs, $R_{S}$ was significantly higher in the Hoggar than in the Bagzane after Bonferroni correction ( $t=3.01,8$ d.f., $P<0.05)$. The fixation index $\left(F_{\mathrm{IS}}\right)$ was not significant for the four mountain ranges supporting a low level of consanguinity in the O. e. laperrinei populations. In addition, we did not find any recent reduction of effective population size in the four investigated populations whatever the model used (data not shown).

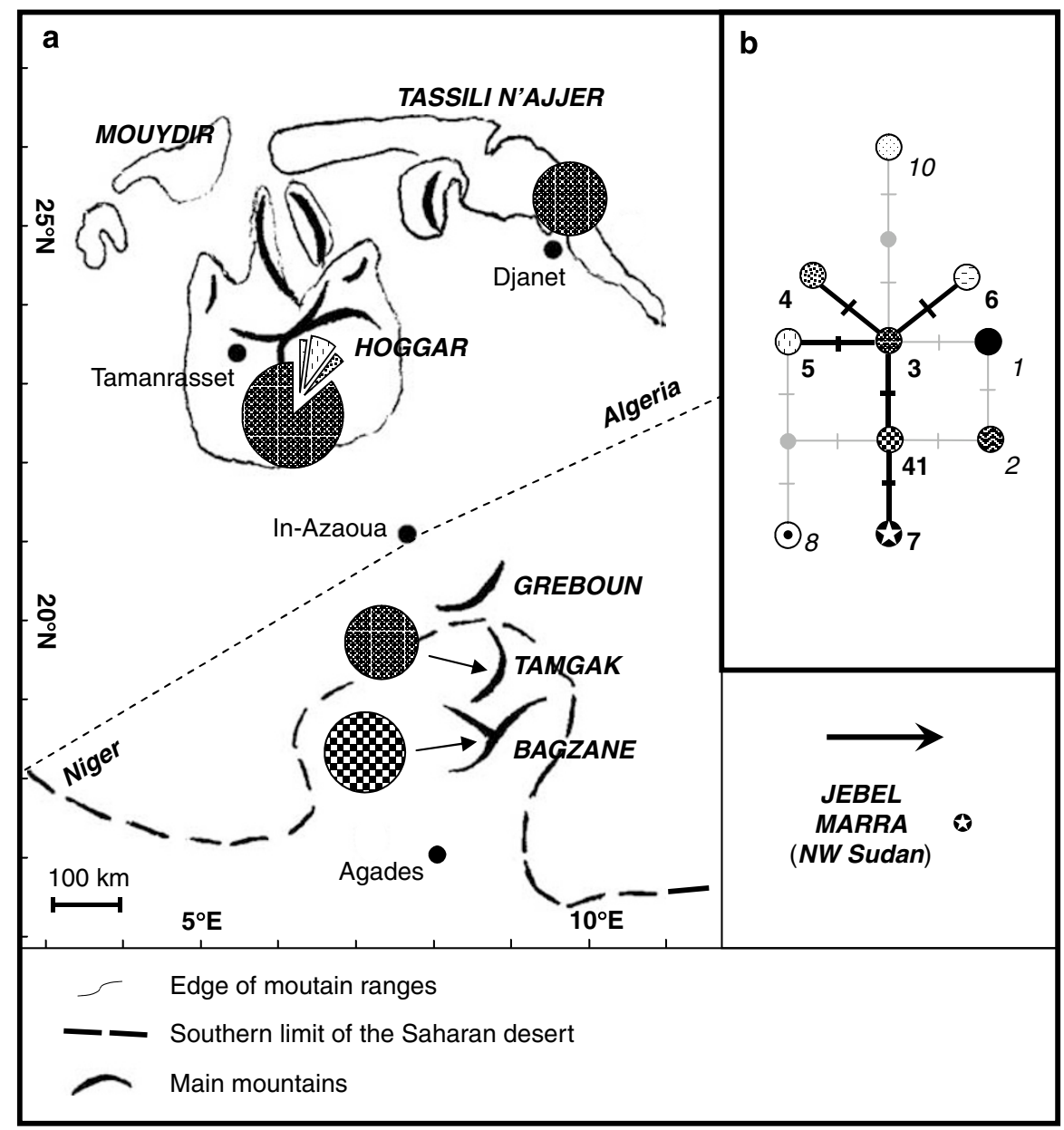

Figure 1 Plastid DNA polymorphism in the O. e. laperrinei populations. (a) Distribution of plastid DNA haplotypes (represented by pie charts) in each mountain range from southern Algeria and northern Niger. Size of pie charts is proportional to the number of individuals analysed. (b) Reduced Median Network (Bandelt et al., 1999) representing phylogenetic relationships of plastid DNA haplotypes in the sublineage E1 (Besnard et al., 2007). Each haplotype is represented by a particular symbol and its corresponding number. The six haplotypes found in O. e. laperrinei populations (nos. 3, 4, 5, 6, 7 and 41) are indicated by a number in bold and their relationships are represented by boldest links. Haplotype 10 (sub-lineage E3; Besnard et al., 2007) is used as out-group. 
Table 2 Total number of alleles $\left(N_{\mathrm{a}}\right)$ observed in O. e. laperrinei populations from Algeria and Niger, allelic richness $\left(R_{\mathrm{S}}\right)$, genetic diversity $\left(H_{\mathrm{T}}\right)$ and global fixation index $\left(F_{\mathrm{IS}}\right)$ computed on nuclear SSR loci and ptDNA haplotypes for each population

\begin{tabular}{|c|c|c|c|c|c|c|c|c|c|c|c|c|c|}
\hline \multirow[t]{2}{*}{ Locus } & \multirow[t]{2}{*}{$\mathrm{N}_{a}$} & \multicolumn{3}{|c|}{ Bagzane } & \multicolumn{3}{|c|}{ Tamgak } & \multicolumn{3}{|c|}{ Tassili $n^{\prime}$ Ajjer } & \multicolumn{3}{|c|}{ Hoggar $^{a}$} \\
\hline & & $\mathrm{R}_{S}$ & $\mathrm{H}_{T}$ & $\mathrm{~F}_{I S}$ & $\mathrm{R}_{S}$ & $\mathrm{H}_{T}$ & $\mathrm{~F}_{I S}$ & $\mathrm{R}_{S}$ & $\mathrm{H}_{T}$ & $\mathrm{~F}_{I S}$ & $\mathrm{R}_{S}$ & $\mathrm{H}_{T}$ & $\mathrm{~F}_{I S}$ \\
\hline \multicolumn{14}{|l|}{ Nuclear SSR } \\
\hline ssrOeUA-DCA1 & 31 & 16.5 & 0.88 & & 19.0 & 0.85 & & 18.9 & 0.91 & & 20.4 & 0.92 & \\
\hline ssrOeUA-DCA3 & 9 & 7.0 & 0.76 & & 8.0 & 0.78 & & 6.0 & 0.64 & & 6.8 & 0.69 & \\
\hline ssrOeUA- DCA8 & 12 & 7.0 & 0.71 & & 4.0 & 0.72 & & 9.0 & 0.80 & & 10.5 & 0.82 & \\
\hline ssrOeUA-DCA9 & 14 & 8.7 & 0.74 & & 10.0 & 0.72 & & 7.0 & 0.76 & & 9.5 & 0.54 & \\
\hline ssrOeUA-DCA14 & 15 & 5.8 & 0.68 & & 7.0 & 0.71 & & 9.9 & 0.78 & & 11.4 & 0.81 & \\
\hline ssrOeUA-DCA15 & 3 & 2.0 & 0.49 & & 2.0 & 0.50 & & 3.0 & 0.25 & & 2.0 & 0.22 & \\
\hline PA(ATT)2 & 3 & 2.0 & 0.06 & & 2.0 & 0.13 & & 3.0 & 0.29 & & 2.0 & 0.09 & \\
\hline GAPU45 & 6 & 3.0 & 0.39 & & 3.0 & 0.52 & & 5.0 & 0.64 & & 4.8 & 0.71 & \\
\hline EMO03 & 16 & 8.0 & 0.68 & & 8.0 & 0.78 & & 7.0 & 0.78 & & 12.4 & 0.83 & \\
\hline Total & 109 & 60.0 & 0.60 & $0.015^{\mathrm{NS}}$ & 63.0 & 0.63 & $0.061^{\mathrm{NS}}$ & 68.8 & 0.65 & $0.010^{\mathrm{NS}}$ & 79.8 & 0.63 & $0.021^{\mathrm{NS}}$ \\
\hline ptDNA & 5 & 1.0 & 0.00 & - & 1.0 & 0.00 & - & 1.0 & 0.00 & - & 4.0 & 0.29 & - \\
\hline
\end{tabular}

Abbreviations: NS, non-significant; SSR, simple sequence repeat.

${ }^{a}$ Computations were done using the 57 genets from the Adrar Heggueghene. Similar values were obtained when all genets sampled in the Hoggar were considered (data not shown).

We then investigated the genetic differentiation between each pair of mountain ranges using $F_{\mathrm{ST}}$ (Table 3). Based on nuclear SSR data, all $F_{\mathrm{ST}}$ values were significantly different from zero and ranged from 2.1 (Tassili n'Ajjer/Hoggar) to $11.6 \%$ (Tassili n'Ajjer/Bagzane). Based on ptDNA polymorphism, we only found a strong genetic differentiation between the Bagzane and all other mountains due to the fixation of a specific haplotype (41; Figure 1). Thus, the most distant mountains (Tassili n'Ajjer and Bagzane) were also the most differentiated. To investigate in more details the genetic structure in our nuclear SSR dataset, a modelbased Bayesian procedure was used to identify clusters of individuals. According to the $\Delta K$ criteria of Evanno et al. (2005), the most likely number of clusters in our dataset is two (Figure $2 \mathrm{~b}$ ). However, $\Delta K$ also showed a peak at $K=4$. Together with the maximum likelihood and the low variability observed for this value (Figure 2a), this number of clusters also fits the required criteria. This suggests that $K=2$ detects the highest level of genetic structure whereas $K=4$ concerns a lower level. Thus, individual assignments to the different clusters averaged over the 10 iterations were considered for $K=2$ (Figure 2c) and $K=4$ (Figure 2d). For $K=2$ (Figure 2c), the clustering allowed the separation of most individuals from the Niger (cluster I) and Algerian (cluster II) mountains. This result indicates that the gene flow between Niger and Algerian populations is particularly limited. Only 17 (7.2\%) individuals (8 from the Hoggar, 2 from the Tassili $\mathrm{n}^{\prime}$ Ajjer and 7 from the Tamgak) were assigned to a cluster with a posterior probability inferior to $80 \%$. Seven individuals (4 from the Tamgak and 3 from the Hoggar) were not assigned to the correct cluster according to their geographic origin with a posterior probability higher than $50 \%$. For $K=4$ (Figure 2d), a more complex pattern was obtained. Individuals from the Bagzane were assigned to cluster IA with a mean probability of $86.7 \%$ and those from the Tamgak were assigned to cluster IB with a mean posterior probability of $79.5 \%$. The assignment of individuals from the Hoggar and the Tassili $n^{\prime}$ Ajjer to a particular cluster was less efficient than in the Niger populations. Thus, individuals from the Hoggar were assigned to cluster IIA with a
Table 3 Pairwise genetic differentiation between populations ( $F_{\mathrm{ST}}$; in percent) based on nuclear microsatellite data

\begin{tabular}{lccc}
\hline & Bagzane & Tamgak & Hoggar \\
\hline Tamgak & $7.4^{*}$ & & \\
Hoggar & $11.1^{*}$ & $9.7^{*}$ & \\
Tassili n'Ajjer & $11.6^{*}$ & $9.4^{*}$ & $2.1^{*}$ \\
\hline
\end{tabular}

Significance values for pairwise test of population differentiation are based on 6000 permutations.

${ }^{*} P<0.001$.

mean posterior probability of $55.3 \%$ and to cluster IIB with a mean posterior probability of $36.1 \%$. Similarly, individuals from the Tassili $\mathrm{n}^{\prime}$ Ajjer were assigned to cluster IIB with a mean posterior probability of $73.9 \%$ and to cluster IIA with a mean posterior probability of $20.4 \%$. These results demonstrate that populations from the Hoggar and Tassili n'Ajjer are poorly differentiated (as previously shown with $F_{\mathrm{ST}}$ ).

\section{Gene flow within population}

Kinship coefficients calculated using SPAGEDi showed a significant decrease with logarithmic geographical distance in the Bagzane (intercept $=0.1725$, slope $=$ $-0.0089, P$-value $<0.0001, R^{2}=0.02$ ) and the Tamgak (intercept $=0.2070, \quad$ slope $=-0.0166, \quad P$-value $=0.0018$, $R^{2}=0.04$ ), indicating that individuals from these mountain ranges are subject to isolation by distance. In contrast, genetic coefficients were not related to logarithmic geographical distance in the Hoggar $(P$-value $=0.15)$ and in the Tassili $n^{\prime}$ Ajjer $(P$-value $=0.29)$. Mean kinship coefficients on distance intervals are presented together with the regression curves (Figure 3).

\section{Discussion}

\section{Population dynamics of the Algerian and Niger} populations

The plastid and nuclear DNA data attest that the Laperrine's olive has maintained a high genetic diversity in the South Algerian Mountains compared to Niger 

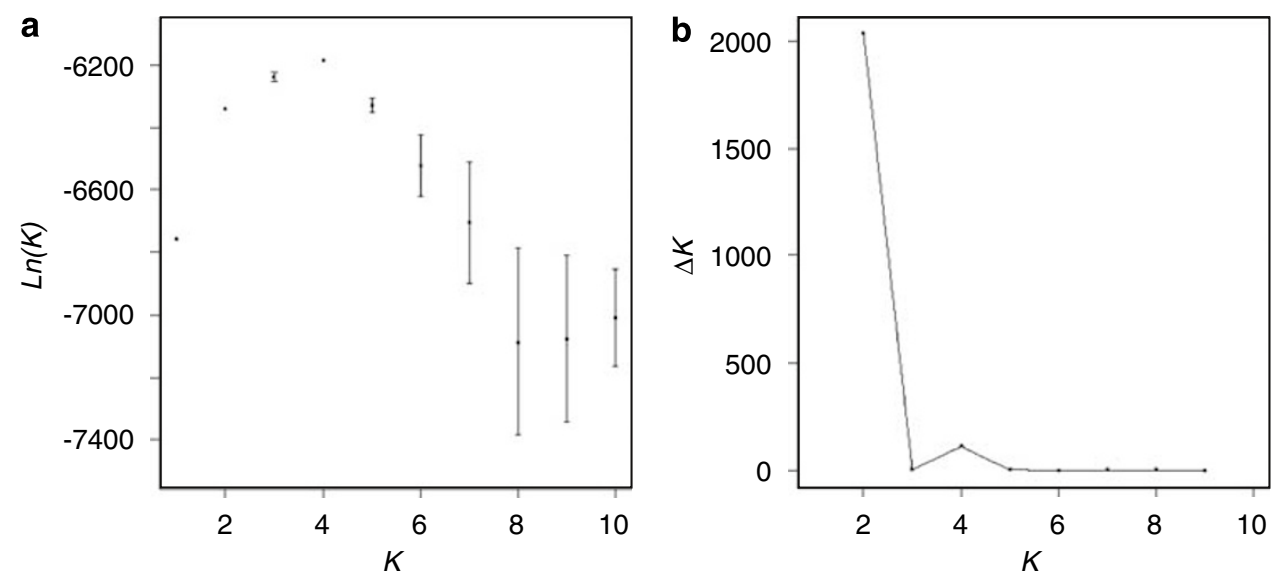

c

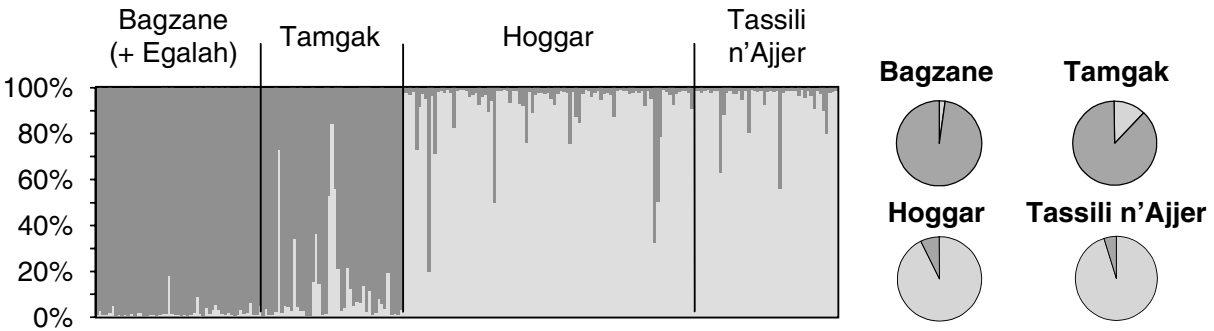

Cluster: $\mathrm{I}$ II

d
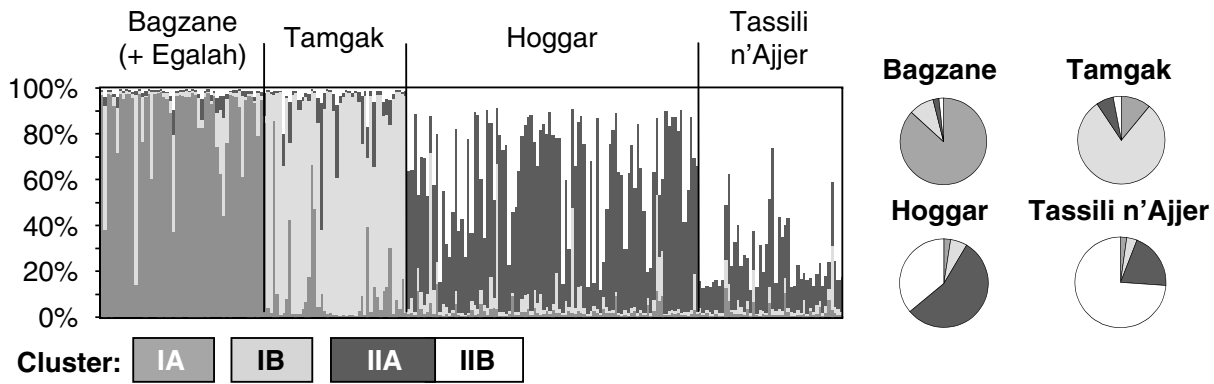

Figure 2 Inference of population structure based on nuclear SSR data and using Bayesian simulations (Pritchard et al., 2000). (a) Mean log likelihood $(\operatorname{Ln}(K) \pm$ s.d.) averaged over the 10 iterations; (b) Absolute values of the second-order rate of change of the likelihood distribution divided by the s.d. of the likelihoods ( $\Delta K$ in Evanno et al., 2005). The percentage of assignment of each individual to the different clusters averaged over 10 iterations is shown for (c) two clusters and (d) four clusters. Each vertical bar represents an individual.

populations (Table 2). This high diversity (particularly in the Hoggar) could be due to an origin of the O. e. laperrinei populations in South Algeria as hypothesized by Wickens (1976). Haplotype no. 3 displayed a basal position in the ptDNA haplotype network (Figure 1), and its high frequency in South Algeria together with the presence of infrequent derived haplotypes (nos. 4, 5 and 6) suggests that the maternal lineage of subsp. laperrinei has probably diversified in the Hoggar. The highest genetic diversity in the Hoggar could also be due to the long persistence of a larger population in South Algeria, which would be less affected by stochastic effects than in other mountains. However, the population size in the Hoggar and the Tamgak are very similar (about several thousands of trees; Anthelme et al., accepted), which would suggest that the low genetic diversity in the Tamgak population was not a consequence of recent loss associated with a reduced effective population size. Other factors, such as levels of populations regeneration (longevity of trees), the population density, the intensity of gene flow between distant patches and the occurrence of barriers to dispersion may also be involved in the different levels of diversity found between the Niger and Algerian mountains (Escudero et al., 2003). The long lifespan of individuals (associated with clonal growth) was proposed to maintain a high genetic diversity in Algerian populations (Baali-Cherif and Besnard, 2005). In the present study, we showed that the frequency of individuals with several ramets is not higher in Algeria (18\%) than in Niger (28.9\%) suggesting that this survival mode does not explain the highest diversity in Algerian mountains.

Our analyses of the genetic differentiation (Table 3, Figure 2) suggest that a combined effect of the geographic distance between the mountains with the presence of desert barriers has limited the occurrence of gene flow between populations. Thus, two levels of structure were found in our nuclear data. The first one allowed the identification of most individuals from Niger and Algerian mountains. These areas are strongly 


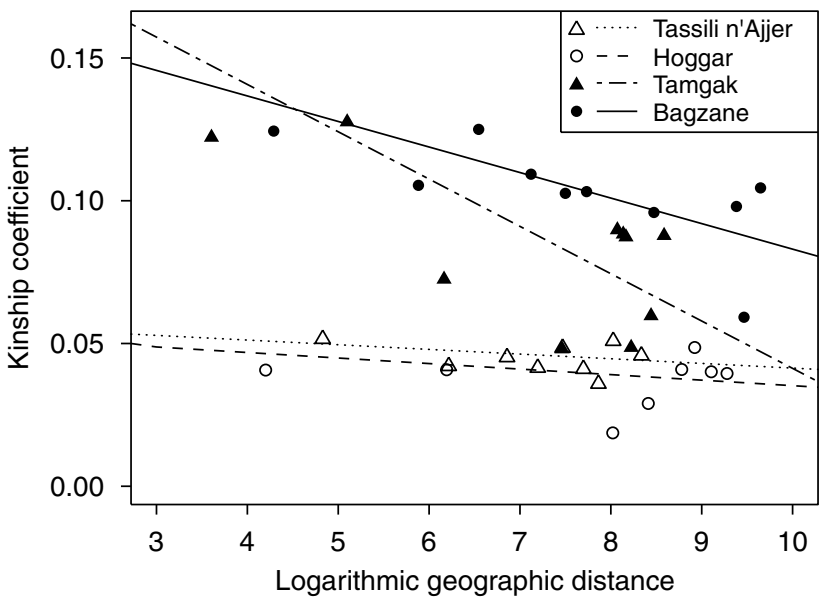

Figure 3 Comparative analysis of the intra-mountain range genetic differentiation (kinship coefficient) according to the logarithmic geographical distance. Mean kinship coefficients (Loiselle et al., 1995) are shown for distance intervals in each mountain range. Regressions curves of the kinship coefficients between all pairs of individuals within a mountain range on the logarithmic geographical distances are added for each mountain range. Regression slopes for the Bagzane and Tamgak were significant $(P$-value $=$ 0.0018 and 0.0001 , respectively) whereas those of the Hoggar and Tassili n'Ajjer were not.

isolated by a desert barrier which may greatly limit long distance gene flow $(>500 \mathrm{~km})$. The second level of structure showed a less pronounced differentiation among the two populations from Niger and Algeria, and in particular between the Hoggar and the Tassili $\mathrm{n}^{\prime}$ Ajjer (Figure 2). From these observations, we cannot exclude possible exchanges between adjacent mountains in relatively recent periods when environmental conditions were more favourable (for instance during the last humid transition of the Sahara about 3500 years ago; Quézel, 1965; Crernaschi et al., 2006). Finally, plastid genome data alone revealed a very strong differentiation of the Bagzane population compared to others (Table 3). This clearly indicates that long distance dispersion by seeds may be particularly infrequent, but unfortunately the low level of variation in the plastid genome did not allow any hypothesis testing for each pair of mountain ranges.

We showed that kinship coefficients were significantly correlated to geographical distance within Niger populations (Figure 3). The detection of a significant SGS at a local scale in this very long-living species is surprising since SGS in out-breeding trees is classically low (Vekemans and Hardy, 2004). However, no SGS was observed within Algerian mountain ranges suggesting that the dynamic of Niger and Algerian populations is affected by different factors. Two non-exclusive explanations can be proposed:

(1) Occurrence of SGS in populations from Niger indicates that individuals from the same patch or from adjacent patches are constituted of relatives. A limited seed and/or pollen dispersal, due to the heterogeneity of the habitat, may explain this observation (Escudero et al., 2003; Troupin et al., 2006; Van Rossum and Triest, 2007). The Laperrine's olive trees are dispersed in patches often isolated by several kilometres in both Niger and Algerian mountains. However, South Algerian mountains (particularly the Hoggar) display a higher altitudinal range allowing the species to persist in a larger area than in Niger (Anthelme et al., accepted). Furthermore, the important network of wadis (interconnected temporary rivers) found in the Hoggar could have facilitated gene flow between distant patches, and thus reducing SGS in this mountain range. In contrast, some physical constraints to dispersion in Niger (due to the absence of a dense network of wadis between the different mounts) may have favoured the appearance and the maintenance of SGS.

(2) A supposed relatively recent colonization of subsp. laperrinei in Niger associated with limited seed dispersal and low density of maternal seed sources may also have created genetic structure within population (Dutech et al., 2002; Jones and Hubbell, 2006). In contrast, the absence of SGS within Algerian populations could be due to long persistence of subsp. laperrinei in this area. Recurrent gene flow between distant patches (migration) may have then obscured SGS in this long-living species.

Based on our current knowledge, it is difficult to determine the exact importance of habitat heterogeneity (affecting dispersion) and historical factors in the maintenance of genetic diversity. A fine ecological description of the habitat is needed to model gene dispersal in each mountain range and to test if the genetic variation found is driven by ecological factors.

\section{On the conservation strategy of populations of subsp. laperrinei}

The long-term persistence of the Laperrine's olive is uncertain due to climatic vicissitudes and the strong human pressures in the Saharan mountains. However, it was previously demonstrated that this tree is able to survive in very dry areas during very long periods using an efficient vegetative growth (Baali-Cherif and Besnard, 2005). The main dilemma of long-living Saharan trees (as Laperrine's olive or C. dupreziana) is the low turnover of their populations. This biological characteristic makes these species vulnerable to environmental changes, and present and past human activities (for example, wood exploitation, browsing) have largely contributed to their regression (Quézel, 1965). Moreover, an absence of sexual reproduction and limited seed dispersal may affect the evolutionary potential of these taxa. Indeed, the present impossibility to assort genes and create new uniting genomes may reduce the opportunities of adaptation to future climatic changes (Honnay and Bossuyt, 2005). However, a great phenotypic plasticity has probably allowed them to persist for very long times (probably several thousand years; Abdoun et al., 2005; Baali-Cherif and Besnard 2005). Seeds of the Laperrine's olive have recently been collected in the field (D Baali-Cherif, unpublished data). Successful germination trials indicated that it may be possible to produce seedlings which could be used to recreate populations. However, this strategy is heavily dependent on the possibility to collect seeds in the field. Most of trees generally do not flower every year, and only a few individuals were shown to be able to produce seeds (D Baali Cherif, unpublished data). 
Thus, only a few individuals may be involved in sexual reproduction and the use of seedlings issued from these trees could have some negative consequences on the genetic diversity of planted populations. Future seed collections should take into account the SGS described in the present study (for example, Chung et al., 1998), and in order to maximize the genetic diversity, individuals must be collected from an area as wide as possible. Therefore, the management strategy of the Saharan relict trees is still an open question, and before to start any programme, the education of human populations will be an essential step to conserve the ecosystems of the Saharan mountains (Quézel, 1997). Our data also suggest that the Hoggar presently acts as an important gene reservoir for the Saharan olive populations, and due to its high altitudinal range, it probably played this role during previous driest episodes of the Pliocene and Pleistocene (Quézel, 1978). Consequently this area may be considered as a priority in future conservation programmes, but very isolated endangered populations displaying evident genetic particularities (for example, Bagzane; Figures 1 and 2) have also to be urgently considered for their endemism.

\section{Acknowledgements}

We thank G Evanno, N Galland, N Salamin and two anonymous reviewers for helpful comments on this manuscript, and A Aboulkader for his help in collecting plant material in the Aïr.

\section{References}

Abdoun F, Beddiaf M (2002). Cupressus dupreziana A. Camus: répartition, dépérissement et régénération au Tassili n'Ajjer, Sahara central. C R Biol 325: 617-627.

Abdoun F, Jull AJT, Guibal F, Thinon M (2005). Radial growth of the Sahara's oldest trees: Cupressus dupreziana A. Camus. Trees Struct Funct 19: 661-670.

Anthelme F, Abdoulkader A, Besnard G: Distribution, shape and clonal growth of the rare endemic tree Olea europaea subsp. laperrinei (Oleaceae) in the Saharan mountains of Niger. Plant Ecol (accepted).

Anthelme F, Waziri Mato M, de Boissieu D, Giazzi F (2006). Dégradation des ressources végétales au contact des activités humaines et perspectives de conservation dans le massif de l'Aïr (Sahara, Niger). VertigO 7: 1-12. (http://www.vertigo. uqam.ca/vol7no2/framerevue.html).

Baali-Cherif D, Besnard G (2005). High genetic diversity and clonal growth in relict populations of Olea europaea subsp. laperrinei (Oleaceae) from Hoggar, Algeria. Ann Bot 96: 823-830.

Baldoni L, Tosti N, Ricciolini C, Belaj A, Arcioni S, Pannelli G et al. (2006). Genetic structure of wild and cultivated olives in the Central Mediterranean Basin. Ann Bot 98: 935-942.

Bandelt HJ, Forster P, Röhl A (1999). Median-joining networks for inferring intraspecific phylogenies. Mol Biol Evol 16: 37-48.

Belaj A, Muñoz-Diez C, Baldoni L, Porceddu A, Barranco D, Satovic Z (2007). Genetic diversity and population structure of wild olives from the north-western Mediterranean assessed by SSR markers. Ann Bot 100: 449-458.

Besnard G, Rubio de Casas R, Vargas P (2003). A set of primers for length and nucleotide-substitution polymorphism in chloroplastic DNA of Olea europaea L. (Oleaceae). Mol Ecol Notes 3: 651-653.

Besnard G, Rubio de Casas R, Vargas P (2007). Plastid and nuclear DNA polymorphism reveals historical processes of isolation and reticulation in the olive tree complex (Olea europaea L.). J Biogeogr 34: 736-752.

Carriero F, Fontanazza G, Cellini F, Giorio G (2002). Identification of simple sequence repeats (SSRs) in olive (Olea europaea L.). Theor Appl Genet 104: 301-307.

Chung MY, Chung GM, Chung MG, Epperson B (1998). Spatial genetic structure in populations of Cymbidium goeringii (Orchidaceae). Genes Genet Syst 73: 281-285.

Coleman M, Liston A, Kadereit JW, Abbott RJ (2003). Repeat intercontinental dispersal and Pleistocene speciation in disjunct Mediterranean and desert Senecio (Asteraceae). Am J Bot 90: 1446-1454.

Crernaschi M, Pelfini M, Santilli M (2006). Cupressus dupreziana: a dendroclimatic record for the middle-late Holocene in the central Sahara. Holocene 16: 293-303.

de la Rosa R, James CM, Tobutt KR (2002). Isolation and characterization of polymorphic microsatellites in olive (Olea europaea L. and their transferability to other genera in the Oleaceae. Mol Ecol Notes 2: 265-267.

Douady CJ, Catzeflis F, Raman J, Springer MS, Stanhope MJ (2003). The Sahara as a vicariant agent, and the role of Miocene climatic events, in the diversification of the mammalian order Macroscelidea (elephant shrews). Proc Natl Acad Sci USA 100: 8325-8330.

Dutech C, Seiter J, Petronelli P, Joly HI, Jarne P (2002). Evidence of low gene flow in a neotropical clustered tree species in two rainforest stands of French Guiana. Mol Ecol 11: 725-738.

Escudero A, Iriondo JM, Torres ME (2003). Spatial analysis of genetic diversity as a tool for plant conservation. Biol Conserv 113: 351-365.

Evanno G, Regnaut S, Goudet J (2005). Detecting the number of clusters of individuals using the software STRUCTURE: a simulation study. Mol Ecol 14: 2611-2620.

Goudet J (1995). FSTAT (version 1.2): a computer programme to calculate F-statistics. J Hered 86: 485-486.

Hardy OJ, Vekemans X (2002). SPAGEDi: a versatile computer program to analyse spatial genetic structure at the individual or population. Mol Ecol Notes 2: 618-620.

Honnay O, Bossuyt B (2005). Prolonged clonal growth: escape route or route to extinction? Oikos 108: 427-432.

Jones FA, Hubbell SP (2006). Demographic spatial genetic structure of the Neotropical tree, Jacaranda copaia. Mol Ecol 15: 3205-3217.

Loiselle BA, Sork VL, Nason J, Graham C (1995). Spatial genetic structure of a tropical understory shrub, Psychotria officinalis (Rubiaceae). Am J Bot 82: 1420-1425.

Luikart G, Cornuet JM (1998). Empirical evaluation of a test for identifying recently bottlenecked populations from allele frequency data. Conserv Biol 12: 228-237.

Maire R (1933). Etudes sur la flore et la végétation du Sahara central. Mémoires de la Société d'Histoire Naturelle de l'Afrique du Nord, no 3, Mission du Hoggar II. pp 166-168, Alger.

Maley J (1980). Les changements climatiques de la fin du Tertiaire en Afrique: leur conséquence sur l'apparition du Sahara et de sa vegetation. In: Williams MAJ, Faure H (eds). The Sahara and the Nile. AA Balkema: Rotterdam. pp 63-86.

McGuire AF, Kron KA (2005). Phylogenetic relationships of European and African Ericas. Int J Plant Sci 166: 311-318.

Médail F, Quézel P, Besnard G, Khadari B (2001). Systematics, ecology and phylogeographic significance of Olea europaea L. ssp. maroccana (Greuter \& Burdet) P. Vargas et al., a relictual olive tree in south-west Morocco. Bot J Linn Soc 137: 249-266.

Nei M (1987). Molecular Evolutionary Genetics. Columbia University Press: New York.

Ortíz-Dorba J, Martínez-Mora C, Correal E, Simón B, Cenis JL (2005). Genetic structure of Atriplex halimus populations in the Mediterranean Basin. Ann Bot 95: 827-834.

Parks JC, Werth CR (1993). A study of spatial features of clones in a population of bracken fern, Pteridium aquilinum (Dennstaedtiaceae). Am J Bot 80: 120-126. 
Piry S, Luikart G, Cornuet JM (1999). Bottleneck: a computer program for detecting recent reductions in the effective population size using allele frequency data. J Hered 90: 502-503.

Pritchard JK, Stephens M, Donnelly P (2000). Inference of population structure from multilocus genotype data. Genetics 155: 945-959.

Quézel P (1965). La végétation du Sahara. Du Tchad à la Mauritanie. Gustav Fisher Verlag: Stuttgart.

Quézel P (1978). Analysis of the flora of Mediterranean and Sahara Africa. Ann MO Bot Gard 65: 479-534.

Quézel P (1997). High mountains of the Central Sahara: dispersal, speciation, origin and conservation of the flora. In: Barakat HN, Hegazy AK (eds). Reviews in Ecology: Desert Conservation and Development. Metropole: Cairo, Egypt, pp 159-175.

Rubio de Casas R, Besnard G, Schoenswetter P, Balaguer L, Vargas P (2006). Extensive gene flow blurs phylogeographic but not phylogenetic signal in Olea europaea L. Theor Appl Genet 113: 575-583.

Saumitou-Laprade P, Vassiliadis C, Epplen JT, Hardt C (2000). Isolation of microsatellite loci for paternity in Phillyrea angustifolia L. (Oleaceae). Mol Ecol 9: 112-114.

Sefc KM, Lopes MS, Mendonça D, Rodrigues dos Santos M, Laimer da Cámara Machado M, da Cámara Machado A
(2000). Identification of microsatellite loci in olive (Olea europaea) and their characterization in Italian and Iberian olive trees. Mol Ecol 9: 1171-1173.

Troupin D, Nathan R, Vendramin GG (2006). Analysis of spatial genetic structure in an expanding Pinus halepensis population reveals development of fine-scale genetic clustering over time. Mol Ecol 15: 3617-3630.

Van Rossum F, Triest L (2007). Fine-scale spatial genetic structure of the distylous Primula veris in fragmented habitat. Plant Biol 9: 374-382.

Vekemans X, Hardy OJ (2004). New insights from fine-scale spatial genetic structure analyses in plant populations. Mol Ecol 13: 921-935.

Weir BS, Cockerham CC (1984). Estimating F-statistics for the analysis of population structure. Evolution 38: 1358-1370.

Weising K, Gardner RC (1999). A set of conserved PCR primers for the analysis of simple sequence repeat polymorphisms in chloroplast genomes of dicotyledonous angiosperms. Genome 42: 9-19.

Wickens GE (1976). Speculations on long distance dispersal and the flora of Jebel Marra (Sudan). Kew Bull 31: 105-150.

Williams JW, Jackson ST, Kutzbach JE (2007). Projected distributions of novel and disappearing climates by 2100AD. Proc Natl Acad Sci USA 104: 5738-5742.

Supplementary Information accompanies the paper on Heredity website (http://www.nature.com/hdy) 